\title{
Banks Performance Determinants: Comparative Analysis between Conventional and Islamic Banks from GCC Countries
}

\author{
Manel Hadriche ${ }^{1}$ \\ ${ }^{1}$ Faculty of Economic Sciences and Management of Nabeul, Tunisia \\ Correspondence: Manel Hadriche, Faculty of Economic Sciences and Management of Nabeul, Tunisia. E-mail: \\ manel.hadriche@yahoo.fr
}

Received: June 15, 2015

Accepted: July 1, 2015

Online Published: August 25, 2015

doi:10.5539/ijef.v7n9p169

URL: http://dx.doi.org/10.5539/ijef.v7n9p169

\begin{abstract}
The aim of this research is to compare and identify the determinants of the performance for Islamic banks with Conventional banks operating in GCC countries from 2005 to 2012. Using a sample of 71 Conventional banks and 46 Islamic banks that operate inside GCC countries for the period 2005-2012 and by using CAMEL test, we find that comparing the profitability of the Islamic and Conventional banks shows that for all the ratios used to measure profitability, Islamic banks are on-average more profitable than the Conventional ones. For performance determinants, results show that bank size affect performance of both Conventional and Islamic banks. Operation cost has a positive and significant effect on performance in Conventional and Islamic banks. The coefficient of credit risk is negative and significant in Conventional banks and positive but non significant in Islamic banks. For macroeconomic variables, inflation and DPG growth haven't a significant effect on Conventional banks performance. For Islamic banks, inflation has a positive and significant coefficient. Results show differences in regards to factors affecting performance between Conventional and Islamic banks. Specifically, credit risk does not affect Islamic bank performance, while inflation and DGP growth do not affect the performance of Conventional banks.
\end{abstract}

Keywords: banks, CAMEL test, conventional, Islamic, performance

\section{Introduction}

Banking sector plays an important role in national and international economic growth by financing business, therefore bank performance evaluation has received increased attention by researchers and practitioners (Tarawneh, 2006). In that framework, many researches have focused on performance evaluation of banks and especially for European and US countries banks. However, limited research has been undertaken to analyse performance in Arabian banking such as GCC countries despite the role and the importance of this region on the economic growth and those studies have only made a comparative analysis between Conventional and Islamic banks and are limited to observe and compare bank performance (Johnes, Izzeldin, \& Pappas, 2012; Onakoya \& Onakoya, 2013). Hence, the lack of literature on performance determinants provides the need to study the factors that can affect banks performance and to relate those factors to performance measurement. Bank performance evaluation is important for many parties such as investors, depositors, bank managers; it helps investors to take decisions in investing or no in such banks, as it also help bank managers to make the best decision that improves banks situation. Our research may give some guidance to depositors to choose the more effective service offered by the banks. From such importance, the present study aims to explore the differences in bank performance between Conventional and Islamic banks in the six GCC countries (Bahrain, Kuwait, Oman, Qatar, Saudi Arabia and the United Arab Emirates), as well as the determinants affecting both the Conventional and Islamic banking systems.

Using a sample of 71 Conventional banks and 46 Islamic banks that operate inside GCC countries for the period 2005-2012, we find that comparing the profitability of the Islamic and Conventional banks shows that for all the ratios used to measure profitability, Islamic banks are on-average more profitable than the Conventional ones. For performance determinants, results show that bank size affect performance of both Conventional and Islamic banks. So, larger banks have better management, use the best technology and diversify their investment this leads to performance improvement. Operation cost has a positive and significant effect on performance in Conventional and Islamic banks. The coefficient of credit risk is negative and significant in Conventional banks 
and positive but non significant in Islamic banks. For macroeconomic variables, inflation and DPG growth haven't a significant affect on Conventional banks performance. For Islamic banks, inflation has a positive and significant coefficient, so an increase in inflation leads to an increase in costs and income, therefore inflation improves bank profitability.

Results show differences in regards to factors affecting performance between Conventional and Islamic banks. Specifically, credit risk does not affect Islamic bank performance, while inflation and DGP growth do not affect the performance of Conventional banks.

This paper makes several contributions. First, this study combines performance analysis of Conventional and Islamic bank and factors affecting bank performance so knowing factors that affect performance helps Islamic and Conventional banks to improve their performance and to remain competitive. Second, to our knowledge, it is the first study in GCC countries that compares and analyses the determinants of bank performance for both Conventional and Islamic using CAMEL rating.

The remainder of this paper is organized as follows: Section 2 discuss the literature review. The third section states the empirical design, including sample, data and empirical model. The fourth section provides variables measurement. Section 5 provides findings. The conclusions and suggestions are given in Section 6.

\section{Literature Review}

\subsection{Review of Islamic and Conventional Banking Performance}

Many researches have focused on comparing Islamic and Conventional banks performance. Some studies support that Islamic banks are more profitable than Conventional banks (Samad \& Hassan, 1999; Iqbal, 2001; Rosly \& AbuBakar, 2003; Safiullah, 2010). In GCC countries, by using 6 different ratios to measure performance and during the period 2006-2009, Parashar and Venkatesh (2010) found that Islamic banks are more profitable than Conventional banks in the region. Ryu et al. (2012) find that Islamic financial system is more profitable than the Conventional financial system and this is due to the fact that Islamic system is less risky and more prudent. Elsiefy (2013) finds the same results in Qatar over the period 2006-2010 by using financial ratio analysis.

There are other studies that support the opposite: Conventional banks are more profitable than Islamic banks, this is due to their high assets and larger market size (Rosly \& Bakar, 2003; Olson \& Zoubi, 2008; Johnes et al., 2014). Ashraf and Rehman (2011) proved that Islamic banks are less profitable than the Conventional banks and justified this result by management inefficiency and the higher operating cost. Ansari and Rehman (2011) compare Islamic and Conventional banks based in Pakistan over the period of 2006-2009 by using different financial ratios representing profitability, liquidity, risk, capital adequacy and efficiency. They found that Islamic banks are more liquid, less efficient and less risky in comparison to Conventional banks. Hanif, Tariq, Tahir and Wajeeh (2012) find that Conventional banks in Pakistan are more profitable and liquid, while Islamic banks are the best in credit risk management and solvency maintenance. Hazzi and Kilani (2013) find that Conventional banks in Malaysia are more profitable than Islamic banks, while the latter is more liquid and less risky. Onakoya et al. (2013) compare the performance of Conventional banks and Islamic banks in the United Kingdom over the period 2007-2011. Finding suggests that Conventional banks are more profitable, more effective and timelier than Islamic banks whose are less risky and more cost-effective.

While others studies proved that there are not significant differences in the financial performance between Islamic and Conventional banks (Samad, 2004; Hamid \& Azmi, 2011). Johnes et al. (2012) compare the performance of Islamic and Conventional banks before, during and after the financial crisis. By using data envelopment analysis (DEA), they found that there is no significant difference between Conventional and Islamic banks in term of efficiency. While, the result of the Meta-Frontier analysis (MFA) suggests that Islamic banks are less efficient than the Conventional one. Rozzani and Rahman (2013) use Stochastic Frontier Analysis to study bank efficiency in Malaysia. They indicate that the levels of efficiency are similar for both Conventional and Islamic banks.

All above studies have not the same result because they are conducted in different countries with different cultures and by using different methods in different periods. We conclude that Islamic banks are more profitable, more liquid, more cost effective, less risky but less operational efficient.

\subsection{Performance Determinants}

A large number of empirical studies have been conducted about determinants of bank performance. Extant literature have investigated performance determinants of Islamic bank in different country such as Pakistan (Akhtar, Ali \& Sadaqat, 2011), Malaysia (Wasiuzzaman \& Tarmizi, 2010; Muda, Shaharuddin, \& Embaya, 2013; 
Abduh \& Idrees, 2013; Abduh \& Alias, 2014). Others have concentrated on Conventional bank in Pakistan (Akhtar et al., 2011), in Greek (Kosmidou, 2008), in Tunisia (Ben Naceur \& Goaied, 2001), in Kenya (Ongore \& Kusa, 2012), in Saudi Arabia (Masood, Aktan, \& Chaudhary, 2009) and in European countries (Kosmidou and Pasiouras, 2007). While very few studies provide evidence on performance determinants for both Islamic and Conventional bank.

In GCC countries, Srairi (2009) has investigated association between bank characteristics, macroeconomic factors, and banks profitability over the period 1999-2006. Results show that credit risk, operational efficiency and capital adequacy affect bank performance of both Islamic and Conventional banks. Results reveal that macroeconomic variables affect positively performance with exception of inflation rate.

As for the most recent literature, Zeitun (2012) conducted a study to assess the factors that affect Islamic and Conventional banks performance in GCC for the period 2002-2009. The study had a sample of 13 Islamic and 38 Conventional banks. The factors studied were foreign ownership, bank specific variable and macroeconomic variables. The study concluded that bank's equity was an important factor in maximizing the profitability for Conventional banks but negatively affected Islamic banks. As for cost to income ratio reflected a negative and significant effect on performance of both banks. The size of the banks supported the economies of scale utilizing the ROE for Islamic banks. However, foreign ownership has no impacts on both banks, while GDP was positively correlated; Inflation was found to be negatively related to the banks performance.

In his research on factors influencing the performance of UAE Islamic and Conventional banks during the year 1996 to 2008, Al-Tamimi (2010) observed that Conventional banks performance are affected by liquidity and concentration, while for Islamic, number of branches and costs are the most significant factors.

The determinants of bank performances can be classified into bank specific and macroeconomic factors (Al-Tamimi, 2010). The relationships of these factors to performance are discussed as below.

Bank Characteristic Variables

Bank specific characteristic are influenced by internal decision of the management and the board strategy. The relevant variables are discussed as follows;

Bank size: Based upon economies of scale theory, the bigger the size of the bank, the higher the profitability. Large banks have more resources to mobilize more funds for their depositors, this lead to higher returns and performance improvement. Extant literature generally demonstrates a positive association between bank size and performance (Delis \& Papanikolaou, 2009; Srairi, 2010; Siddiqui \& Shoaib, 2011; Eriki \& OSifo, 2015). Some other studies such as Kosmidou and Pasiouras (2007) found that for extremely larger banks, size can have a negative effect due to bureaucratic and other reasons.

Credit risk: An increase in credit risk leads to a decrease in profitability. Loans portfolio are the main source of revenues for banks but equally considered as largest source of credit risk due to the problem of adverse selection. So, increased nonperforming loans can lead to credit risk hence decline in profitability. Srairi (2009) and Wasiuzzaman and Tarmizi (2010) found a significant positive relationship between profitability and credit risk. Bank loans are the main sources of revenue; therefore if borrowers are able to repay their debt and interest, banks profitability increase.

Operational cost: According to Cebenoyan and Strahan (2001) and Srairi (2010), operational cost is negatively related to performance. Banks that engage in an important lending have the more ability to manage productive operations. An increase in lending leads to a decrease in production costs, and, consequently, an increase in bank performance. Chen (2009) found that higher income leads to higher operational cost and there bye to higher risk that affect negatively bank performance.

\section{Macroeconomic Factors}

To isolate the effects of the bank characteristic variables on profitability, it is important to control for other factors that can determine profitability. Macroeconomic conditions obviously affect the assets and liabilities mixture of the banks. To capture the macroeconomic conditions we use the following variables: GDP growth and inflation.

GDP growth: an increase in GDP growth leads to an increase in banks profitability because the default risk is lower in upturns than in downturns. Therefore, when the GDP growth is high, demand for both interest and non-interest activities increase, thereby improving the performance of banks.

Inflation: an increase in inflation leads to an increase in costs and income, therefore inflation improves bank profitability. Athanasoglou et al. (2009), Sufian and Habibbullah (2009), Delis and Papanikolaou (2009) showed 
that inflation affects positively and significantly profitability. On the other hand, Srairi (2009) could not find any significant relationship between inflation and performance.

\section{Samples and Data}

The population for this study is all Islamic and Conventional banks that operate inside GCC countries. The first sample contains 71 Conventional banks. The second sample contains 46 Islamic banks. A panel data analysis was employed in this study for the period 2005-2012. All data on the bank's financial statements are collected from Bank-Scope database. Macroeconomic variables are obtained from IMF World Economic Outlook database.

\section{Variables Measurement}

\subsection{Performance Variables}

To measure and compare the performance of Islamic and Conventional banks, CAMEL rating is used. The CAMEL framework is a set of variables that include the capital adequacy, asset quality, management quality, earnings ability and liquidity.

\section{a) Capital Adequacy}

Capital adequacy measures the financial strength and viability of the banks in terms of capital over assets like investment and loans. In our study, capital adequacy is measured by equity to total assets ratio. Capital adequacy represents the proportion of total assets financed by shareholders.

b) Asset Quality

Assets of banks are composed essentially by loans. The quality of loans of any banks is very important for investors or depositors because it gives idea on the creditworthiness of the banks. In this paper, we measure asset quality by non performing loans over total loans.

\section{c) Management Quality}

Management Quality means management superiority. Managers must safe banks operations; therefore, they must have skills and ability to control the cost, increase productivity and profitability. In this study, we use total loans over total deposits LD to measure management quality.

d) Earnings

In this study we employ two performance measures to determine banks profitability:

ROE: Return on Equity is net income over to total equity. ROE assesses efficiency of banks to generate profit from the money that had been invested by shareholders.

ROA: Return on Assets is net income to total assets. ROA assesses efficiency of banks to generate profit by using its assets.

e) Liquidity

Liquidity is very crucial for all banks, because liquidity problem may lead to insolvency and may end up with bankruptcy. Liquidity is the ability of easily convert assets into cash. In this study, we use two measures for liquidity: Liquid assets over total deposits and net loans over total deposit and short tern funding.

Table 1 presents a summary of all ratios used in camel rating following the studies of Srairi (2010) and Rozzani (2013).

Table 1. Summary of ratios

\begin{tabular}{lll}
\hline Methodology & Component & Financial Measurement \\
\hline \multirow{3}{*}{ CAMELS Rating } & Capital Adequacy & Equity Capital/Total Assets \\
& Asset Quality & Non-Performing Loans/Total Loans \\
& Management Quality & Total loan over total deposit \\
Earnings Quality & Return on Assets \\
& Return on Equity \\
& Liquidity & Liquid Assets/Deposit and Short Term Funding \\
& Net Loans/Deposit and Short Tern Funding \\
\hline
\end{tabular}

First, we calculate ratios for all six indicator of performance. Second, we put on average weightage for banks by 
ranking of 1 to 5 . Third, we combine all the individual ranking to obtain an overall rank for bank performance (Sarker, 2006; Kambhamettu, 2012).

The dependent variable used in the present study is the performance measure obtained from the CAMEL composite rating. The application of the CAMEL composite rating as a dependent variable is similar to the studies of Reynaud (2010) and Rozzani and Rahman (2013).

Table 2. Interpretation of CAMEL composite rating

\begin{tabular}{|c|c|c|c|}
\hline Rating & Rating Range & Rating Analysis & Interpretation \\
\hline 1 & $1.0-1.4$ & Strong & Bank is basically good in every aspect. \\
\hline 2 & $1.6-2.4$ & Satisfactory & Bank is primarily good but has several identified weaknesses. \\
\hline 3 & $2.5-3.4$ & $\begin{array}{l}\text { Fair, with some categories } \\
\text { to be watched }\end{array}$ & $\begin{array}{l}\text { Bank has financial, operational, or compliance weaknesses to be } \\
\text { watched that provide reason for supervisory concern. }\end{array}$ \\
\hline 4 & $3.5-4.4$ & $\begin{array}{l}\text { Marginal, with some risk of } \\
\text { failure }\end{array}$ & $\begin{array}{l}\text { Bank has serious financial weaknesses that can damage its risk of } \\
\text { failure future capability to ensure normal growth and development. }\end{array}$ \\
\hline 5 & $4.5-5.0$ & $\begin{array}{l}\text { Unsatisfactory with a high degree } \\
\text { of failure }\end{array}$ & $\begin{array}{l}\text { Bank has critical financial weaknesses that indicate the degree of } \\
\text { failure probability of failure to be extremely high in the near future. }\end{array}$ \\
\hline
\end{tabular}

Notes. As cited in Rozzani (2013); Sarker (2006).

To test association between the determinants and level of performance measured by CAMEL rating for the period of 2005 to 2012, two models are developed: one for Conventional banks and one for Islamic banks.

Our model is as follows:

$$
\text { RATE it }=\beta 0+\beta 1 S I Z E \text { it }+\beta 2 \text { OPRC it }+\beta 3 \text { CRED it }+\beta 4 G D P \text { it }+\beta 5 I N F i t+\varepsilon
$$

Where,

RATE $=$ is CAMEL composite rating,

SIZE $=$ is $\log$ of total assets,

$\mathrm{OPRC}=$ is ratio of cost by income,

$\mathrm{CRED}=$ is natural logarithm of non-performing loans,

GDP $=$ is GDP Growth,

$\mathrm{INF}=$ is inflation rate,

$\mathrm{i}=$ financial institution (Conventional and Islamic banks)

$\mathrm{t}=$ year.

\section{Results}

\subsection{Performance Comparison}

Table 3. Descriptive analysis for CAMEL rating

\begin{tabular}{lcccc}
\hline & \multicolumn{2}{c}{ Conventional } & \multicolumn{2}{c}{ Islamic } \\
\hline Composite & Mean & Standard Deviation & Mean & Standard Deviation \\
Capital Adequacy & 3.379 & 0.741 & 4.078 & 0.709 \\
Asset Quality & 3.188 & 0.991 & 3.885 & 1.494 \\
Management Quality & 3.315 & 1.123 & 4.815 & 0.602 \\
Earnings Quality (Return on Assets) & 3.354 & 0.852 & 4.225 & 0.858 \\
Earnings Quality (Return on Equity) & 3.416 & 0.852 & 3.578 & 1.309 \\
Liquidity (Net Loans/Deposits and Short Term Funding) & 3.202 & 1.135 & 3.858 & 1.146 \\
Liquidity (Liquid Assets/Deposits and Long Term Funding) & 3.361 & 0.849 & 3.883 & 1.192 \\
\hline
\end{tabular}

To compare performances between and among banks, we use Independent Sample t-test and ANOVA. 
Table 4. T test and ANOVA test

\begin{tabular}{lccc}
\hline & F value & P value & T value \\
\hline Composite & 4.89 & 0.027 & 14.331 \\
Capital Adequacy & 116.65 & 0.000 & 0.000 \\
Asset Quality & 262.58 & 0.000 & 23.498 \\
Management Quality & 0.042 & 0.838 & 15.199 \\
Earnings Quality (Return on Assets) & 247.238 & 0.000 & 2.299 \\
Earnings Quality (Return on Equity) & 2.785 & 0.095 & 8.595 \\
Liquidity (Net Loans/Deposits and Short Term Funding) & 123.876 & 0.000 & 0.000 \\
Liquidity (Liquid Assets/Deposits and Long Term Funding) & 86.322 & 0.000 & 0.000 \\
\hline
\end{tabular}

Table 3 presents descriptive analysis for Conventional and Islamic banks' CAMEL rating. Results demonstrates that a small differences exist between the composite rating of Conventional (3.379) and Islamic (4.078) banks. Table 4 reports the results of the two sample t-test and ANOVA test whose show that significant difference exists between the two groups.

Results show that Islamic banks are better in maintaining capital adequacy, asset quality, management quality and earning and the difference is significant (see Table 4). The results suggest that, in terms of capital adequacy, Islamic banks are better in investment decisions, in responding to balance sheet shocks and in attracting more profit. The finding also shows a lack of management ability in Conventional banks, which are more concentrated on expansion strategies rather than performance-oriented strategies.

For the liquidity, the results of the two sample t-test and ANOVA test indicate that no significant difference exists between the two groups for liquid assets over deposit and long term funding ratio; but net loans over total deposits and short term funding rating is higher in Islamic banks than Conventional banks. Overall results of liquidity ratios show that Islamic banks are more liquid than Conventional banks this is due to the fact that Islamic bank are based on religion invest only in Sharia approved projects also, this high liquidity is related to the fact that Islamic bank do not have enough investment opportunities. According to Haron and Abdul Rahman (2012), liquidity management is one of the most critical tasks in the operations of financial institutions.

Comparing the profitability of the Islamic and Conventional banks shows that for all the ratios used to measure profitability, Islamic banks are on-average more profitable than the Conventional ones. Given the extraordinary growth in Islamic finance in recent years, this should not come as a surprise.

The averages of all bank performance variables are higher for the Islamic banks. That might be an indication of the Islamic banks being bigger than the Conventional institutions in terms of business activity. However, the standard deviation is in all cases higher for the Islamic banks, indicating a higher distribution of the Islamic banks than the Conventional ones.

\subsection{Performance Determinants}

Table 5 reports results of performance determinants. Results show a positive and significant coefficient at $5 \%$ level for bank size both in Conventional and Islamic banks, which supports the results of Srairi (2009). So, larger banks will perform better because they may have more diversified investment opportunities, better management and employ better technology. Hence, from the results, it can be concluded that Conventional and Islamic banks would be more profitable if bank size is the determining variable.

With reference to table 5, operation cost has a positive and significant effect at $10 \%$ level on performance in Conventional and Islamic banks. The result is in contrast to the studies of Chen (2009).

The coefficient of credit risk is negative and significant in Conventional banks and positive but non significant in Islamic banks. The positive relationship is consistent with Conventional financial theory, which pustules that an increase in credit risk leads to an increase in bank performance. Negative relationship is in contrast to the studies of Srairi (2009), and Wasiuzzaman and Tarmizi (2010).

For macroeconomic variables, inflation and DPG growth haven't a significant effect on Conventional banks performance. For Islamic banks, inflation has a positive and significant coefficient, so an increase in inflation leads to an increase in costs and income, therefore inflation improves bank profitability.

Results show differences in regards to factors affecting performance between Conventional and Islamic banks. Specifically, credit risk does not affect Islamic bank performance, while inflation and DGP growth do not affect the performance of Conventional banks. 
Table 5. Performance determinants of conventional and Islamic banks

\begin{tabular}{lcccccc}
\hline & \multicolumn{3}{c}{ Conventionnel } & \multicolumn{3}{c}{ Islamic } \\
\hline Constant & Coefficient & z-value & p-value & Coefficient & z-value & p-value \\
Bank size & 2.004 & 2.72 & 0.007 & 1.127 & 1.26 & 0.208 \\
Operational cost & 0.276 & 2.44 & 0.015 & 0.341 & 2.24 & 0.025 \\
Credit risk & 0.007 & 1.77 & 0.077 & 0.0008 & 1.78 & 0.074 \\
Inflation & -0.144 & -1.95 & 0.051 & 0.032 & 0.51 & 0.613 \\
DGP growth & -0.011 & -1.47 & 0.141 & 0.017 & 2.43 & 0.015 \\
R2 & 0.007 & 0.71 & 0.478 & -0.023 & -2.41 & 0.016 \\
$\mathrm{~N}$ & & 0.186 & & & 0.187 & \\
\end{tabular}

\section{Conclusion}

The present study compares bank performance between Conventional and Islamic banks in GCC countries. Using a sample of 71 Conventional banks and 46 Islamic banks that operate inside GCC countries for the period 2005-2012, we find that comparing the profitability of the Islamic and Conventional banks shows that for all the ratios of CAMEL test, Islamic banks are on-average more profitable than the Conventional ones. Results show that Islamic banks are better in investment decisions, in responding to balance sheet shocks and in attracting more profit. The finding also shows a lack of management ability in Conventional banks, which are more concentrated on expansion strategies rather than performance-oriented strategies.

Overall results of liquidity ratios show that Islamic banks are more liquid than Conventional banks this is due to the fact that Islamic bank are based on religion invest only in Sharia approved projects, also, this high liquidity is related to the fact that Islamic bank do not have enough investment opportunities.

The averages of all bank performance variables are higher for the Islamic banks. That might be an indication of the Islamic banks being bigger than the Conventional institutions in terms of business activity. However, the standard deviation is in all cases higher for the Islamic banks, indicating a higher distribution of the Islamic banks than the Conventional ones. For performance determinants, results show that bank size affect performance of both Conventional and Islamic banks, which supports the results of Srairi (2009). So, larger banks will perform better because they may have more diversified investment opportunities, better management and use better technology. Operation cost has a positive and significant effect on performance in Conventional and Islamic banks. The coefficient of credit risk is negative and significant in Conventional banks and positive but non significant in Islamic banks. For macroeconomic variables, inflation and DPG growth haven't a significant affect on Conventional banks performance. For Islamic banks, inflation has a positive and significant coefficient so an increase in inflation leads to an increase in costs and income, therefore inflation improves bank profitability.

Results show differences in regards to factors affecting performance between Conventional and Islamic banks. Specifically, credit risk does not affect Islamic bank performance, while inflation and DGP growth do not affect the performance of Conventional banks.

This research has some limitations. First, many banks are excluded from our sample due to the missing data for many years over the period of the study. Second, some other variables were not included because of the lack of information such as interest rate....

Our research has implications for stakeholders, investors public and policy makers. First, this research finding can help potential investors and shareholders to make the best investment decision. Second, results can be beneficial to public, customers and potential customers to choose the more effective service delivery mechanism offered by the banks. Third, the bank regulator is interested to find the power of the financial system. Therefore this research will guide policy makers and regulators on the gaps that need to avoid any financial distress. Future researches can study others determinants of bank performance and include banks from other countries to better understand and evaluate bank performance.

\section{References}

Abduh, M., \& Alias, A. (2014). Factors Determine Islamic Banking Performance in Malaysia: A Multiple Regression Approach. Journal of Islamic Banking and Finance, 31, 44-54.

Abduh, M., \& Idrees, Y. (2013). Determinants of Islamic Banking Profitability in Malaysia. Australian Journal of Basic and Applied Sciences, 7(2), 204-210. 
Akhtar, M. F., Ali, K., \& Sadaqat, S. (2011). Factors Influencing the Profitability of Islamic Banks of Pakistan. International Research Journal of Finance and Economics, 66, 117-124.

Al-Tamimi, H. H. (2010). Factors influencing performance of the UAE Islamic and conventional national banks. Global Journal of Business Research, 4, 1-9.

Ansari, S., \& Rehman, A. (2011). Financial Performance of Islamic and Conventional Banks in Pakistan: A Comparative Study. International Conference on Islamic Economic and Finance.

Ashraf, M. M., \& Rehman, Z. (2011). The Performance Analysis of Islamic and Conventional Banks: The Pakistan's Perspective. Journal of Money, Investment and Banking, 22, 99-113.

Athanasoglou, P. P., Brissimis, S. N., \& Delis, M. D. (2009). Bank-specific, industry specific and macroeconomic determinants of bank profitability. Journal of International Financial Markets, Institutions and Money, 18, 121-136. http://dx.doi.org/10.1016/j.intfin.2006.07.001

Chen, C. (2009). Bank efficiency in Sub-Saharan African middle-income countries. Working Paper, International Monetary Fund. http://dx.doi.org/10.5089/9781451871616.001

Delis, M. D., \& Papanikolaou, N. I. (2009). Determinants of bank efficiency: Evidence from a semi-parametric methodology. Managerial Finance, 35(3), 260-275. http://dx.doi.org/10.1108/03074350910931771

Elsiefy, E. (2013). Comparative Analysis of Qatari Islamic Banks Performance versus c conventional Banks Before, during and After the Financial crisis. International Journal of Business and Commerce, 3(3), 11-41.

Eriki, P. O., \& OSifo, O. (2015). Determinants of performance efficiency in Nigerian banking industry: A DEA approach. International Journal of Economics, Commerce and Management, 3(2), 1-13.

Hamid, M. A., \& Azmi, S. M. (2011). The Performance of Banking during 2000-2009: Bank Islam Malaysia Berhad and Conventional Banking in Malaysia. International Journal of Economics and Management Sciences, 1(1), 1-18.

Hanif, M., Tariq, M., Tahir, A., \& Wajeeh, M. (2012). Comparative Performance Study of Conventional and Islamic Banking in Pakistan. International Research Journal of Finance and Economics, 83, 62-72.

Haron, N. H., \& Abdul Rahman, R. (2012). Financial distress-Detection model for Islamic banks. International Journal of Trade, Economics and Finance, 3(3), 158-163.

Hazzi, O. A., \& Kilani, M. I. (2013). The Financial Performance Analysis of Islamic and traditional Banks: Evidence from Malaysia. European Journal of Economics, Finance and Administrative Sciences, 57, 133-144.

Johnes, J., Izzeldin, M., \& Pappas, V. (2012). A comparison of performance of Islamic and Conventional banks 2004 to 2009. Lancaster University, The Department of Economics, Economics Working Paper Series. http://dx.doi.org/10.2139/ssrn.2071615

Kambhamettu, S. R. (2012). Relative performance of commercial banks in India using CAMEL approach. Research Journal of Economics and Business Studies, 1(4), 1-10.

Kosmidou, K. (2008). The determinants of banks' profits in Greece during the period of EU financial integration. Managerial Finance, 34(3), 146-159. http://dx.doi.org/10.1108/03074350810848036

Kosmidou, M., \& Pasiouras, F. (2007). Factors influencing the profitability of domestic and foreign commercial banks in the European Union. Research in International Business and Finance, 21(2), 222-237. http://dx.doi.org/10.1016/j.ribaf.2006.03.007

Masood, O., Aktan, B., \& Chaudhary, S. (2009). An Empirical Study on Banks Profitability in the KSA: A Co-Integration Approach. African Journal of Business Management, 3(8), 374-382.

Muda, M., Shaharuddin, S., \& Embaya, A. (2013). Comparative Analysis of Profitability Determinants of Domestic and Foreign Islamic Banks in Malaysia. International Journal of Economics and Financial Issues, 3, 559-569.

Naceur, S. B., \& Goaied, M. (2001). The determinants of the Tunisian deposit banks' performance. Journal of Applied Financial Economics, 11, 317-319. http://dx.doi.org/10.1080/096031001300138717

Olson, D., \& Zoubi, T. (2008). Using Accounting Ratios to Distinguish between Islamic and Conventional banks in the GCC Region. International Journal of Accounting, 43, 45-65. http://dx.doi.org/10.1016/j.intacc.2008.01.003 
Onakoya, A. B., \& Onakoya, A. O. (2013). The Performance of Conventional and Islamic Banks in the United Kingdom: A Comparative Analysis. Journal of Research in Economics and International Finance, 2(2), 29-38.

Ongore, V. O., \& Kusa, G. B. (2012). Determinants of financial performance of commercial banks in Kenya. International Journal of Economics and Financial issues, 3(1), 237-252.

Parashar, S., \& Venkatesh, J. (2010). How did Islamic banks do during global financial crisis? Banks and Bank Systems, 5, 54-62.

Reynaud, J. P. M. (2010). Could efficiency analysis help in predicting bank failure? The case of the 2001 Turkish crisis. Review of Middle East Economics and Finance, 6(1), 1-21. http://dx.doi.org/10.2202/1475-3693.1255

Rosly, S. A., \& Bakar, M. A. A. (2003). Performance of Islamic and mainstream banks in Malaysia. International Journal of Social Economics, 20, 1249-1265. http://dx.doi.org/10.1108/03068290310500652

Rozzani, N., \& Rahman, R. A. (2013). Determinants of Bank Efficiency: Conventional versus Islamic.

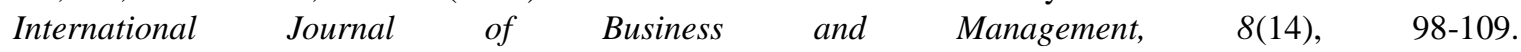
http://dx.doi.org/10.5539/ijbm.v8n14p98

Rozzani, N. (2013). Determinants of Bank Performance: Conventional versus Islamic. Journal Pengurusan, 39, 129-139.

Ryu, K. P., Piao, S. Z., \& Nami, D. (2012). A Comparative study between the Islamic and conventional banking systems and its implications. Scholarly J. Bus. Admin., 2(5), 48-54.

Safiullah, M. (2010). Superiority of Conventional Banks \& Islamic Banks of Bangladesh: A Comparative Study. International Journal of Economics and Finance, 2(3). http://dx.doi.org/10.5539/ijef.v2n3p199

Samad, A. (2004). Performance of interest-free Islamic banks vis-à-vis interest-based conventional banks of Bahrain. IIUM Journal of Economics and Management, 12(2), 1-15.

Samad, A., \& Hassan, M. K. (1999). The Performance of Malaysian Islamic Bank during 1984-1997: An Exploratory Study. International Journal of Islamic Financial Services, 1(3), 1-14.

Sarker, A. A. (2006). CAMELS rating system in the context of Islamic banking: A proposed ' $\mathrm{S}$ ' for Shariah framework. Journal of Islamic Economics, Banking and Finance, 2(2), 1-26.

Siddiqui, M. A., \& Shoaib, A. (2011). Measuring performance through capital structure: Evidence from banking sector of Pakistan. African Journal of Business Management, 5(5), 1871-1879.

Srairi, S. A. (2009). Factors influencing the profitability of conventional banks and Islamic banks in GCC countries. Review of Islamic Economics, 13(1), 5-30.

Srairi, S. A. (2010). Cost and profit efficiency of conventional and Islamic banks in GCC countries. Journal of Productivity Analysis, 34(1), 45-62. http://dx.doi.org/10.1007/s11123-009-0161-7

Sufian, F., \& Habibbullah, M. S. (2009). Bank specific and macroeconomic determinants of bank profitability: Empirical evidence from the China banking sector. Frontiers of Economics in China, 4(2), 274-291. http://dx.doi.org/10.1007/s11459-009-0016-1

Tarawneh, M. (2006). A Comparison of Financial Performance in the Banking Sector: Some Evidence from Omani Commercial Banks. International Research Journal of Finance and Economics, 3, 101-112.

Wasiuzzaman, S., \& Tarmizi, H. (2010). Profitability of Islamic Banks in Malaysia: An Empirical Analysis. Journal of Islamic Economics, Banking and Finance, 6(4), 53-68.

Zeitun, R. (2012). Determinants of Islamic and Conventional Banks Performance in GCC Countries Using Panel Data Analysis. Global Economy and Finance Journal, 5(1), 53-72.

\section{Copyrights}

Copyright for this article is retained by the author(s), with first publication rights granted to the journal.

This is an open-access article distributed under the terms and conditions of the Creative Commons Attribution license (http://creativecommons.org/licenses/by/3.0/). 